\title{
PENGELOLAAN MANAJEMEN KINERJA PADA SATUAN KERJA PERANGKAT DINAS DENGAN MENGGUNAKAN SISTEM TERPADU BERBASIS E-SAKIP (STUDI KASUS DI DINAS PENDAPATAN KAB. BULELENG)
}

\author{
PUTU ARIK GITA SASMITA, MADE FERY CAHYADI, NI LUH FEBRY SUKMA \\ ANDRIYANI, KADEK NETY MUTIARI, NI PUTU SRIASIH \\ Jurusan Akuntansi, Universitas Pendidikan Ganesha, Singaraja, Bali, Indonesia
}

\begin{abstract}
Abstrak
Penelitian ini bertujuan untuk mengetahui tentang SAKIP dan Manajemen kinerja pada satuan kerja perangkat dinas, apa itu E-SAKIP, dan pengelolaan manajemen kinerja pada satuan kerja perangkat dinas dengan adanya penerapan E-SAKIP di Dinas Pendapatan Kab.Buleleng. penelitian deskriptif dengan menggunakan metode analisis deskriptif kualitatif. Hasil dari penelitian ini yaitu E-Sakip diterapkan di Kabupaten Buleleng sejak Juni 2017 lalu. Sistem ini merupakan sistem untuk meningkat akuntabilitas kinerja instansi serta meningkatkan kualitas pelayanan. Sistem E-SAKIP mampu menjamin sistem akuntabilitas kinerja instansi pemerintah mampu berjalan sesuai target yang dicapai sesuai dengan data yang ada dilapangan, karena sistem online data yang diinput kesistem tidak dapat di ubah. Sehingga kualitas kinerja dari suatu SKPD terukur dengan baik.
\end{abstract}

Kata kunci: Pengelolaan, Manajemen, Kerja, E-SAKIP

\begin{abstract}
This research aims to know about the SAKIP and performance management in the working unit of the service device, what is E-SAKIP, and management of performance management in the service device work unit with the implementation of E-SAKIP in the Revenue Service Kab. Buleleng. Descriptive research using qualitative descriptive analysis methods. The result of this research is the E-Sakip was implemented in Buleleng Regency since June 2017. This system is a system to increase the performance accountability of the agency and improve service quality. E-SAKIP system is able to guarantee the system of performance accountability of government agencies are able to run according to the target achieved according to the data that is in the field, because the online system of data inputted Kesistem can not be changed. So the performance quality of a SKPD is well measured.
\end{abstract}

Keywords: management, management, work, E-SAKIP

\section{Pendahuluan}

Dewasa ini, dibentuknya sebuah peraturan berupa Peraturan Presiden Nomor 29 Tahun 2014 tentang Sistem Akuntabilitas Kinerja Instansi Pemerintahan, dimana sistem ini merupakan integrasi dari sistem perencanaan, sistem penganggaran dan sistem pelaporan kinerja, yang selaras dengan pelaksanaan sistem akuntabilitas keuangan. Dalam hal ini, setiap organisasi diwajibkan mencatat dan melaporkan setiap penggunaan keuangan negara serta kesesuaiannya dengan ketentuan yang berlaku. Sistem akuntabilitas kinerja instansi pemerintah (SAKIP) merupakan penerapan manajemen kinerja pada sektor publik yang sejalan dan konsisten dengan penerapan reformasi birokrasi, yang berorientasi pada pencapaian outcomes dan upaya untuk mendapatkan hasil yang lebih baik.

Sedangkan LAKIP adalah Laporan Akuntabilitas Kinerja Instansi Pemerintahan. LAKIP merupakan produk akhir SAKIP yang menggambarkan kinerja yang dicapai oleh suatu instansi pemerintah atas pelaksanaan program dan kegiatan yang dibiayai APBN/APBD. Penyusunan LAKIP berdasarkan siklus anggraan yang berjalan 1 tahun. Dalam pembuatan LAKIP suatu instansi pemerintah harus dapat menentukan besaran 
kinerja yang dihasilkan secara kuantitatif yaitu besaran dalam satuan jumlah atau persentase. Manfaat dari LAKIP bisa dijadikan bahan evaluasi terhadap instansi pemerintah yang bersangkutan selama 1 tahun anggaran.

Lahirnya SAKIP LAKIP adalah berasal dari Inpres No.7 Tahun 1999 tentang Akuntabilitas Instansi Pemerintah dimana didalamnya disebutkan Mewajibkan setiap Instansi Pemerintah sebagai unsur penyelenggara Pemerintahan untuk mempertanggungjawabkan pelaksanaan tugas pokok, dipandang perlu adanya pelaporan akuntabilitas kinerja instansi Pemerintah.

Dengan adanya sistem SAKIP dan LAKIP bergeser dari pemahaman "Berapa besar dana yang telah dan akan dihabiskan" menjadi "Berapa besar kinerja yang dihasilkan dan kinerja tambahan yang diperlukan, agar tujuan yang telah ditetapkan dalah akhir periode bisa tercapai".

Dalam penilaian LAKIP, materi yang dievaluasi meliputi 5 komponen. Komponen pertama adalah perencanaan kinerja, terdiri dari renstra, rencana kinerja tahunan, dan penetapan kinerja dengan bobot 35. Komponen kedua, yakni pengukuran kinerja, yang meliputi pemenuhan pengukuran, kualitas pengukuran, dan implementasi pengukuran dengan bobot 20 .

Nilai tertinggi dari evaluasi LAKIP adalah AA (memuaskan), dengan skor 85 s.d 100, sedangkan A (sangat baik) skornya 75 s.d 85, CC (cukup baik) dengan skor 50 s.d 65, C (agak kurang) dengan skor 30 s.d 50, dan nilai D (kurang) dengan skor 0 s.d 30.

E-SAKIP adalah aplikasi Sistem Akuntabilitas Kinerja Instansi Pemerintah yang bertujuan untuk memudahkan proses pemantauan dan pengendalian kinerja dalam rangka meningkatkan akuntabilitas dan kinerja unit kerja.Aplikasi ini menampilkan proses perencanaan kinerja, penganggaran kinerja, keterkaitan kegiatan/sub kegiatan dalam pencapaian target kinerja, dan monitoring serta evaluasi pencapaian SAKIP merupakan rangkaian sistematik dari berbagai aktivitas, alat dan prosedur yang dirancang untuk tujuan penetapan dan pengukuran, pengumpulan data, pengikhtisaran, pengklasifikasian dan juga pelaporan kinerja pada instansi pemerintah dalam rangka pertanggungjawaban dan peningkatan kinerja. Prioritas penerapan sistem manajemen pemerintah ini diharapkan mampu meningkatkan akuntabilitas yang berorientasi pada hasil (outcome).

Dinas Pendapatan Kabupaten Buleleng adalah salah satu Satuan Kerja Perangkat Dinas (SKPD) Pemkab Buleleng. Dinas Pendapatan Kab. Buleleng terbagi menjadi beberapa bidang dalam menjalankan tugasnya dan tugas pokoknya menghimpun setiap sumber pendapatan yang ada di daerah Buleleng . Informasi dari Kepala Bagian Setda Kab Buleleng, Ir.Made Budhi Setiawan mengatakan bahwa salah satu SKPD yang belum mengoptimalkan pengoperasian E-SAKIP dalam pengevaluasian kinerjanya serta belum menguasai sistem secara optimal sehingga data yang masuk ke sistem belum terstruktur dengan baik adalah Dinas Pendapatan Kab. Buleleng. Oleh karena itu, berdasarkan permasalahan diatas maka penulis tertarik untuk melakukan penelitian yang berjudul "Pengelolaan Manajemen Kinerja Pada Satuan Kerja Perangkat Dinas Dengan Menggunakan Sistem Terpadu Berbasis E-SAKIP (Studi Di Dinas Pendapatan Kab. Buleleng)"

Berdasarkan permasalahan diatas maka rumusan masalah yang akan diambil yaitu apa itu SAKIP dan Manajemen kinerja pada satuan kerja perangkat dinas, apa itu E-SAKIP, dan bagaimana pengelolaan manajemen kinerja pada satuan kerja perangkat dinas dengan adanya penerapan E-SAKIP di Dinas Pendapatan Kab.Buleleng.

\section{Metode Penelitian}

Dalam penelitian ini yang menjadi fokus penelitian akan dibahas oleh penulis adalah bagaimana Pengelolaan manajemen kinerja pada satuan kerja perangkat dinas dengan adanya penerapan E-SAKIP di Dinas Pendapatan Kab.Buleleng. Jenis penelitian yang penulis lakukan adalah penelitian deskriptif dengan menggunakan metode analisis deskriptif kualitatif.Pada bagian ini penulis akan menganalisis data yang diperoleh dilapangan. Dalam penelitian ini teknik analisis data yang digunakan oleh Linclon dan Guba 
dalam Moleong (2007:112) yang terdiri dari empat kegiatan yang dilakukan dari awal hingga selesainya kegiatan yaitu :

a. Pengumpulan data yaitu yang dilakukan melalui observasi atau wawancara lalu dilakukan pencatatan dan pengetikan serta penyuntingan seperlunya.

b. Reduksi yakni mengadakan pemilihan terhadap data yang ada,mempertajam data analisis, meringkas serta membuang data yang tidak diperlukan.

c. Menyediakan data yakni menyediakan data serta menyederhanakan data yang telah diperoleh agar dapat memudahkan penelitian dalam penarikan kesimpulan.

d. Penarikan kesimpulan yakni melakukan verifikasi dengan meninjau ulang catatan atau data yang diperoleh serta menganalisis sebab akibatnya termasuk bertukar pikiran dengan anggota kelompok.

\section{Hasil dan Pembahasan}

\subsection{Pengertian Sakip}

SAKIP adalah Sistem Akuntabilitas Kinerja Instansi Pemerintahan, dimana sistem ini merupakan integrasi dari sistem perencanaan, sistem penganggaran dan sistem pelaporan kinerja, yang selaras dengan pelaksanaan sistem akuntabilitas keuangan.

Dalam hal ini, setiap organisasi diwajibkan mencatat dan melaporkan setiap penggunaan keuangan negara serta kesesuaiannya dengan ketentuan yang berlaku. Cikal bakal lahirnya SAKIP LAKIP adalah berasal dari Inpres No.7 Tahun 1999 tentang Akuntabilitas Instansi Pemerintah dimana didalamnya disebutkan Mewajibkan setiap Instansi Pemerintah sebagai unsur penyelenggara Pemerintahan untuk mempertanggungjawabkan pelaksanaan tugas pokok, dipandang perlu adanya pelaporan akuntabilitas kinerja instansi Pemerintah.

Dengan adanya sistem SAKIP dan LAKIP bergeser dari pemahaman "Berapa besar dana yang telah dan akan dihabiskan" menjadi "Berapa besar kinerja yang dihasiulkan dan kinerja tambahan yang diperlukan, agar tujuan yang telah ditetapkan dalah akhir periode bisa tercapai".

SAKIP di Indonesia Berdasarkan Instruksi Presiden (Inpres) Nomor 7 tahun 1999 tentang akuntabilitas kinerja instansi pemerintah dan keputusan Lembaga Administrasi Negara (LAN) Nomor 589/IX/Y/1999 tentang pedoman penyusunan Pelaporan Akuntabilitas Instansi Pemerintah, yang telah diperbaiki dengan Keputusan LAN Nomor 239/IX/6/8/2003, maka pemerintah (institusi di bawah naungan pemerintahan) wajib untuk melaksanakan sistem pengukuran kinerja (SPK). Inpres No. 7 Tahun 1999 menyatakan bahwa akuntabilitas kinerja instansi pemerintah adalah perwujudan kewajiban suatu instansi pemerintah untuk mempertanggungjawabkan keberhasilan atau kegagalan pelaksanaan misi organisasi dalam mencapai tujuan dan sasaran yang telah ditetapkan melalui pertanggungjawaban secara periodik (BPKP 2007).

Terbitnya Inpres No. 7 Tahun 1999 juga menjadi pintu gerbang reformasi birokrasi pasca orde baru. Bersamaan dengan itu, lahir pula Sistem Akuntabilitas dan Kinerja Instansi Pemerintah (SAKIP) sebagai salah satu konsekuensi dari diterapkannya otonomi daerah di Indonesia. SAKIP sebagai manifestasi dari Inpres No. 7 Tahun 1999 menuntut instansi pemerintah mempertanggungjawabkan dan menjelaskan mengenai keberhasilan/kegagalan tingkat kerja yang dicapainya dengan melaporkan dokumen yang disebut Laporan Akuntabilitas dan Kinerja Instansi Pemerintah (LAKIP). Untuk pemerintah daerah tingkat provinsi dan kabupaten/kota, yang dimaksud instansi pemerintah adalah Satuan Kerja Perangkat Daerah (SKPD). SKPD adalah suatu unit kerja pemerintah yang diberikan hak dan tanggungjawab untuk mengelola sendiri administrasi dan keuangannya.

\subsection{Pengertian E-Sakip}

E-Sakip adalah aplikasi Sistem Akuntabilitas Kinerja Instansi Pemerintah secara elektronik (E-SAKIP) yang bertujuan untuk memudahkan proses pemantauan dan pengendalian kinerja Satuan Kerja Perangkat Daerah (SKPD) di lingkungan Pemerintah Kabupaten/Kota dalam rangka meningkatkan akuntabilitas dan kinerja SKPD khususnya 
pada kinerja Pemerintah Kabupaten /Kota pada umumnya. Informasi yang dihasilkan dari aplikasi E-Sakip ini dapat diakses oleh publik, dengan harapan masyarakat dapat turut serta memantau, menilai dan memberikan masukan kepada Pemerintah Kabupaten /Kota bilamana terdapat SKPD yang kinerjanya kurang maksimal.

Aplikasi E-Sakip ini menampilkan informasi secara waktu sebenarnya (real time) meliputi:

1. RPJM Daerah (Rencana Pembangunan Jangka Menengah Daerah)

Sistem Perencanaan Pembangunan Nasional adalah satu kesatuan tata cara perencanaan pembangunan untuk menghasilkan rencana-rencana pembangunan dalam jangka panjang, jangka menengah, dan tahunan yang dilaksanakan oleh unsur penyelenggara negara dan masyarakat di tingkat Pusat dan Daerah. Sistem ini adalah pengganti dari Garis-Garis Besar Haluan Negara (GBHN) dan mulai berlaku sejak tahun 2005.

Rencana Pembangunan Jangka Panjang Nasional (disingkat RPJP Nasional), adalah dokumen perencanaan pembangunan nasional untuk periode 20 (dua puluh) tahun. RPJP Nasional untuk tahun 2005 sampai dengan 2025 diatur dalam UndangUndang Nomor 17 Tahun 2007. Pelaksanaan RPJP Nasional 2005-2025 terbagi dalam tahap-tahap perencanaan pembangunan dalam periodisasi perencanaan pembangunan jangka menengah nasional 5 (lima) tahunan.

Rencana Pembangunan Jangka Menengah Nasional, (disingkat RPJM Nasional), adalah dokumen perencanaan untuk periode 5 (lima) tahun yang terdiri dari :

RPJM Nasional I Tahun 2005-2009,

RPJM Nasional II Tahun 2010-2014,

RPJM Nasional III Tahun 2015-2019,

RPJM Nasional IV Tahun 2020-2024.

RPJM tersebut kemudian dijabarkan ke dalam Rencana Kerja Pemerintah (RKP) setiap tahunnya

Rencana Kerja Pemerintah (disingkat RKP) adalah rencana pembangunan tahunan nasional, yang memuat prioritas pembangunan nasional, rancangan kerangka ekonomi makro yang mencakup gambaran perekonomian secara menyeluruh termasuk arah kebijakan fiskal, serta program kementerian/lembaga, lintas kementerian/lembaga kewilayahan dalam bentuk kerangka regulasi dan pendanaan yang bersifat indikatif. RKP merupakan pedoman bagi penyusunan Anggaran Pendapatan dan Belanja Negara (APBN).

Rencana Pembangunan Jangka Panjang Daerah (disingkat RPJP Daerah) adalah dokumen perencanaan pembangunan daerah untuk periode 20 (dua puluh). RPJP Nasional untuk tahun 2005 sampai dengan 2025 diatur dalam Undang-Undang Nomor 17 Tahun 2007. RPJP Daerah yang memuat visi, misi, dan arah Pembangunan Jangka Panjang Daerah disusun mengacu kepada RPJP Nasional.

Rencana Pembangunan Jangka Menengah Daerah, (disingkat RPJM Daerah) adalah dokumen perencanaan pembangunan daerah untuk perioda 5 (lima) tahunan yang merupakan penjabaran dari visi, misi, dan program kepala daerah dengan berpedoman pada RPJP Daerah serta memerhatikan RPJM Nasional.

Rencana Pembangunan Jangka Menengah Daerah (RPJM Daerah) merupakan penjabaran dari visi, misi, dan program Kepala Daerah yang penyusunannya berpedoman pada Rencana Pembangunan Jangka Panjang Daerah (RPJP Daerah) dan memperhatikan Rencana Pembangunan Jangka Menengah Nasional.

RPJM Daerah memuat arah kebijakan keuangan daerah, strategi pembangunan daerah, kebijakan umum, dan program Satuan Kerja Perangkat Daerah, lintas Satuan Kerja Perangkat Daerah, dan program kewilayahan disertai dengan rencana-rencana kerja dalam kerangka regulasi dan kerangka pendanaan yang bersifat indikatif.

RPJM Daerah dijabarkan dalam Rencana Kerja Pemerintah Daerah (RKPD) dan mengacu pada Rencana Kerja Pemerintah (RKP), memuat rancangan kerangka ekonomi daerah, prioritas pembangunan daerah, rencana kerja, dan pendanaannya, baik yang dilaksanakan langsung oleh pemerintah maupun yang ditempuh dengan mendorong partisipasi masyarakat. 
RPJM Daerah dilengkapi dengan matriks indikasi program yang merinci tujuan beserta indikator dan targetnya, sasaran beserta indikator dan targetnya, kebijakan, dan program untuk masing-masing misi. Selengkapnya dapat di download di bawah ini

2. Rencana Strategis SKPD

Rencana Strategis SKPD adalah suatu dokumen Perencanaan yang berorientasi pada hasil yang ingin dicapi dalam kurun waktu 1-5 tahun sehubungan dengan tugas dan fungsi SKPD serta disuse dengan memperhitungkan perkembangan lingkungan strategis.

Rencana Strategis SKPD atau Rencana Strategis Satuan Kerja Perangkat Daerahmerupakan satu dokumen rencana resmi daerah yang dipersyaratkan bagimengarahkan pelayanan SKPD khususnya dan pembangunan daerah padaumumnya dalam jangka waktu 5 (lima) tahun ke depan masa pimpinan Kepala Daerah dan Wakil Kepala Daerah Terpilih. Sebagai suatu dokumenrencana yang penting sudah sepatutnya Pemerintah Daerah, DPRD dan masyarakat memberikan perhatian penting pada kualitas proses penyusunan dokumen Renstra SKPD, dan tentunya diikuti dengan pemantauan, evaluasi,dan review berkala atas implementasinya.

Rencana strategis SKPD yang selanjutnya disingkat dengan Renstra SKPD adalah dokumen perencanaan SKPD untuk periode 5 (lima) tahun

Sistematika penulisan Renstra SKPD, paling sedikit mencakup (Permendagri 54 Tahun 2010):

- Pendahuluan

- Gambaran pelayanan SKPD

- Isu-isu strategis berdasarkan tugas pokok dan fungsi

- Visi, misi, tujuan dan sasaran, strategi dan kebijakan

- Rencana program, kegiatan, indikator kinerja, kelompok sasaran dan pendanaan indikatif;

- Indikator kinerja SKPD yang mengacu pada tujuan dan sasaran RPJMD

3. Rencana Kinerja Tahunan tingkat SKPD dan kabupaten

Rencana Kinerja Tahunan SKPD merupakan proses penjabaran lebih lanjut dari sasaran dan program yang telah ditetapkan dalam Rencana Stratejik (Renstra) SKPD yang mencakup periode tahunan. Rencana Kinerja Tahunan SKPD menggambarkan kegiatan tahunan yang akan dilaksanakan oleh instansi pemerintah (SKPD) dan indikator kinerja beserta target-targetnya berdasarkan program, kebijakan, dan sasaran yang telah ditetapkan dalam rencana strategik. Target kinerja tahunan di dalam rencana kinerja ditetapkan untuk seluruh indikator kinerja yang ada pada tingkat sasaran dan kegiatan. Target kinerja tersebut merupakan komitmen bagi instansi untuk mencapainya dalam satu periode tahunan.

Rencana Kinerja Tahunan (RKT) merupakan bagian dari rangkaian proses perencanaan yang memuat sasaran strategis, indikator kinerja serta target kinerja dan merupakan penjabaran tahunan dari rencana strategis SKPD. Sasaran strategis, indikator kinerja dan target kinerja pada prinsipnya merupakan variabel yang termuat dalam dokumen renstra, dengan demikian RKT hanya tinggal menjabarkan saja setiap tahunnya sasaran yang hendak dilaksanakan sampai dengan lima tahun kedepan.

4. Perjanjian Kinerja tingkat SKPD dan kabupaten

Perjanjian kinerja adalah lembar/dokumen yang berisikan penugasan dari pimpinan instansi yang lebih tinggi kepada pimpinan instansi yang lebih rendah untuk melaksanakan program/kegiatan yang disertai dengan indikator kinerja. Melalui perjanjian kinerja, terwujudlah komitmen penerima amanah dan kesepakatan antara penerima dan pemberi amanah atas kinerja terukur tertentu berdasarkan tugas, fungsi dan wewenang serta sumber daya yang tersedia. Kinerja yang disepakati tidak dibatasi pada kinerja yang dihasilkan atas kegiatan tahun bersangkutan, tetapi termasuk kinerja (outcome) yang seharusnya terwujud akibat kegiatan tahun-tahun sebelumnya. Dengan demikian target kinerja yang diperjanjikan juga mencakup outcome yang dihasilkan dari 
kegiatan tahun-tahun sebelumnya, sehingga terwujud kesinambungan kinerja setiap tahunnya.

Tujuan Penyusunan Perjanjian Kinerja

- Sebagai wujud nyata komitmen antara penerima dan pemberi amanah untuk meningkatkan integritas, akuntabilitas, transparansi, dan kinerja Aparatur;

- Menciptakan tolok ukur kinerja sebagai dasar evaluasi kinerja aparatur;

- Sebagai dasar penilaian keberhasilan/kegagalan pencapaian tujuan dan sasaran organisasi dan sebagai dasar pemberian penghargaan dan sanksi;

- Sebagai dasar bagi pemberi amanah untuk melakukan monitoring, evaluasi dan supervisi atas perkembangan/kemajuan kinerja penerima amanah;

- Sebagai dasar dalam penetapan sasaran kinerja pegawai

5. LKjIP (Laporan Kinerja Instansi Pemerintah)

Penyusunan LKjIP intinya adalah melaporkan hasil pencapaian kinerja yang diukur dengan membandingkan rencana kinerja yang telah ditetapkan secara utuh mengacu pada rencana strategis. Adapun pengukuran pencapaian kinerja Laporan Kinerja Instansi Pemerintah (LkJIP) dengan melihat sasaran, indikator sasaran, target yang diinginkan, realisasi, dan pencapaian target. Setiap keberhasilan dan kegagalan capaian indikator sasaran, diberikan analisis tentang hambatan dan kendala serta penyebab belum tercapainya target yang diinginkan.

6. Evaluasi Capaian Kinerja tingkat SKPD dan kabupaten

Evaluasi kinerja kegiatan menunjukan capaian kinerja suatu unit instansi pemerintah dalan suatu kurun waktu tertentu. Evaluasi kinerja kegiatan setidaknya menunjukan penilaian atas keberhasilan/ kegagalan pelaksanaan kegiatan sesuai dengan sasaran dan tujuan yang telah ditetapkan dalam kerangka perencanaan strategis. Selanjutnya sesuai dengan atribut indicator kinerja dan capaian kinerja kegiatan yang telah ditetapkan, evaluasi kinerja kegiatan dilakukan. Teknik dan metode yang digunakan dalam menganalisis kinerja kegiatan, yang pertama-tama dilakukan adalah dengan melihat sejauh mana adanya kesesuaian antara program dan kegiatannya.

Program dan kegiatan yang dievaluasi seharusnya merupakan program dan kegiatan sebagaimana tertuang dalam perencanaan strategis instansi yang bersangkutan. Bagi instansi pemerintah yang bersangkutan evaluasi yang dilakukan harus merujuk kepada indicator kinerja yang telah ditetapkannya, baik itu input, proses, output, outcome, benefit dan impactnya, dan pula capaiannya.

\subsection{Pengelolaan manajemen kinerja pada satuan kerja perangkat dinas dengan adanya penerapan E-SAKIP di Dinas Pendapatan Kab.Buleleng}

Menurut Peraturan Pemerintah No 8 tahun 2006 tentang Pelaporan Keuangan dan Kinerja Instansi Pemerintah mengamanatkan bahwa dalam rangka pertanggungjawaban pelakaanaan APBN/APBD, setiap Entitas Pelaporan wajib menyusun dan menyajikan Laporan Keuangan dan Laporan Kinerja. Sebagai tindak lanjut dari PP No 8 tahun 2008, Pemerintah kembali menerbitkan Peraturan Presiden No 29 tahun 2009 tentang Sistem Akuntabilitas Kinerja Instansi Pemerintah yang mengamanatkan bahwa setiap Pemerintah Daerah dan SKPAD mempunyai kewajiban untuk menyusun, menyajikan, laporan kinerja secara berkala (Tri Wulan) maupun Tahunan. SAKIP adalah Sistem Akuntabilitas Kinerja Instansi Pemerintahan, dimana sistem ini merupakan integrasi dari sistem perencanaan, sistem penganggaran dan sistem pelaporan kinerja, yang selaras dengan pelaksanaan sistem akuntabilitas keuangan.

SAKIP sebagai manifestasi dari Inpres No. 7 Tahun 1999 yang menuntut instansi pemerintah mempertanggung jawabkan dan menjelaskan mengenai keberhasilan /kegagalan tingkat kerja yang dicapainya dengan melaporkan dokumen yang disebut Laporan Akuntabilitas dan Kinerja Instansi Pemerintah (LAKIP). Untuk pemerintah daerah tingkat provinsi dan kabupaten/kota, yang dimaksud instansi pemerintah adalah Satuan 
Kerja Perangkat Daerah (SKPD). SKPD adalah suatu unit kerja pemerintah yang diberikan hak dan tanggungjawab untuk mengelola sendiri administrasi dan keuangannya.

E-Sakip adalah aplikasi Sistem Akuntabilitas Kinerja Instansi Pemerintah secara elektronik (E-SAKIP) yang bertujuan untuk memudahkan proses pemantauan dan pengendalian kinerja Satuan Kerja Perangkat Daerah (SKPD) di lingkungan Pemerintah Kabupaten/Kota dalam rangka meningkatkan akuntabilitas dan kinerja SKPD pada khususnya dan kinerja Pemerintah Kabupaten/Kota pada umumnya. Informasi yang dihasilkan dari aplikasi E-Sakip ini dapat diakses oleh publik, dengan harapan masyarakat dapat turut serta memantau, menilai dan memberikan masukan kepada Pemerintah Kabupaten/ Kota bilamana terdapat SKPD yang kinerjanya kurang maksimal. meliputi:

Aplikasi E-Sakip ini menampilkan informasi secara waktu sebenarnya (real time)

- RPJMD (Rencana Pembangunan Jangka Panjang Daerah)

- Rencana Strategis SKPD

- Rencana Kinerja Tahunan tingkat SKPD dan kabupaten

- Indikator Kinerja Utama tingkat SKPD dan kabupaten

- Perjanjian Kinerja tingkat SKPD dan kabupaten

- LKjIP (Laporan Kinerja Instansi Pemerintah)

- Evaluasi Capaian Kinerja tingkat SKPD dan kabupaten

- Hasil Evaluasi dari Kementerian Pendayagunaan Aparatur Negara dan Reformasi Birokrasi

E-SAKIP diterapkan di Kabupaten Buleleng sejak Juni 2017 lalu. Sistem ini merupakan sistem untuk meningkat akuntabilitas kinerja instansi serta meningkatkan kualitas pelayanan. E-SAKIP dilaksanakan secara online. Adapun sistem E-SAKIP pelaksanaanya diawali dengan penyuluhan dan pelatihan secara serentak. Kemudian, sistem kerjanya seluruh SKPD yang ada diwilayah Pemkab membuat perencanaan kinerja dengan aplikasi E-SAKIP sesuai dengan pedoman yang telah disediakan dan diberikan dengan cara input apa saja perencanaan kinerjanya, lalu menginput pengukuran kinerja, kemudian melakukan pelaporan kinerja, selanjutnya evaluasi kinerja dan yang terakhir sistem akan bekerja untuk menilai keseluruhan data apakah suatu SKPD mampu melaksanakan kinerjanya dengan baik sehingga mampu dinilai prestasi kinerjanya dengan menghasilkan berupa ouput data informasi yang akan dilihat dan dinilai oleh masyarakat. Dan sistem E-SAKIP mampu menjamin sistem akuntabilitas kinerja instansi pemerintah mampu berjalan sesuai target yang dicapai sesuai dengan data yang ada dilapangan , karena sistem online data yang diinput kesistem tidak dapat di ubah. Sehingga kualitas kinerja dari suatu SKPD terukur dengan baik.

Berdasarkan hasil wawancara yang kami dapatkan dengan narasumber Bapak Ir. Made Budhi Setiawan, beliau mengatakan bahwa SKPD yang paling sering dalam mengalami kendala dalam pengaplikasian E-SAKIP adalah Dispenda Kab.Buleleng. Setelah itu, peneliti melakukan survei ke Dispenda Kab.Buleleng dan menemukan kendala dari pengaplikasian E-SAKIP di Dispenda Kab.Buleleng, yakni:

1. Dinas Pendapatan Kab.Buleleng mengalami beberapa kendala, diantaranya: sistem yang sangat rumit, sehingga menyebabkan pegawai bingung dalam menginput data , kesulitan dalam mengoperasikan E-SAKIP karena aplikasinya bersifat online, sehingga pada saat melakukan proses input data awal mengalami kekeliruan atau kesalahan data tidak dapat diubah .

2. Dispenda Kab.Buleleng sering mengalami kesulitan karena peraturan sering berubah, sehingga perlu melakukan penyesuaian pada tahap teknis di Dispenda Kab.Buleleng, kesulitan dalam mengoperasikan E-SAKIP karena sering kali eror dan belum mahir dalam mengoprasikan aplikasi.

Saat kendala seperti diatas dialami oleh pihak pemerintahan desa, biasanya akan segera menghubungi secara langsung Bagian Organisasi Sekretariat Daerah Kabupaten Buleleng . Selain itu untuk memperlancar kinerja sistem E-SAKIP yang baru saja diterapkan ini, Bagian Organisasi Sekretariat Daerah melaksanakan peninjauan secara rutin ke setiap 
SKPD serta mengoptimalakan peninjauan dan pembimbingan terhadap SKPD yang masih sering mengalami kendala seperti Dinas Pendapatan Kab.Buleleng.

\section{Simpulan dan Saran}

\subsection{Simpulan}

Menurut Peraturan Pemerintah No 8 tahun 2006 tentang Pelaporan Keuangan dan Kinerja Instansi Pemerintah mengamanatkan bahwa dalam rangka pertanggungjawaban pelakaanaan APBN/APBD, setiap Entitas Pelaporan wajib menyusun dan menyajikan Laporan Keuangan dan Laporan Kinerja. Sebagai tindak lanjut dari PP No 8 tahun 2008, Pemerintah kembali menerbitkan Peraturan Presiden No 29 tahun 2009 tentang Sistem Akuntabilitas Kinerja Instansi Pemerintah yang mengamanatkan bahwa setiap Pemerintah Daerah dan SKPAD mempunyai kewajiban untuk menyusun, menyajikan, laporan kinerja secara berkala (Tri Wulan) maupun Tahunan. SAKIP adalah Sistem Akuntabilitas Kinerja Instansi Pemerintahan, dimana sistem ini merupakan integrasi dari sistem perencanaan, sistem penganggaran dan sistem pelaporan kinerja, yang selaras dengan pelaksanaan sistem akuntabilitas keuangan.

Kegiatan Akuntabilitas Kinerja Instansi Pemerintahan dapat dilaksanakan dengan baik tentunya harus didukung diantaranya oleh sumber daya manusia yang kompeten dan berkualitas serta sistem dan prosedur pengelolaan kinerja Instansi Pemerintahan yang memadai. Oleh karenanya, pemerintah Kabupaten/kota harus memiliki struktur organisasi pengelolaan kinerja, uraian tugas, bagan alir, dan kriteria yang menjadi acuan dalam kegiatan pengelolaan kinerja instansi pemerintah.

E-Sakip adalah aplikasi Sistem Akuntabilitas Kinerja Instansi Pemerintah secara elektronik (E-SAKIP) yang bertujuan untuk memudahkan proses pemantauan dan pengendalian kinerja Satuan Kerja Perangkat Daerah (SKPD) di lingkungan Pemerintah Kabupaten/Kota dalam rangka meningkatkan akuntabilitas dan kinerja SKPD pada khususnya dan kinerja Pemerintah Kabupaten/Kota pada umumnya. Informasi yang dihasilkan dari aplikasi E-Sakip ini dapat diakses oleh publik, dengan harapan masyarakat dapat turut serta memantau, menilai dan memberikan masukan kepada Pemerintah Kabupaten/ Kota bilamana terdapat SKPD yang kinerjanya kurang maksimal.

E-SAKIP diterapkan di Kabupaten Buleleng sejak Juni 2017 lalu. Sistem ini merupakan sistem untuk meningkat akuntabilitas kinerja instansi serta meningkatkan kualitas pelayanan. E-SAKIP dilaksanakan secara online. Adapun sistem E-SAKIP pelaksanaanya diawali dengan penyuluhan dan pelatihan secara serentak. Kemudian, sistem kerjanya seluruh SKPD yang ada diwilayah Pemkab membuat perencanaan kinerja dengan aplikasi E-SAKIP sesuai dengan pedoman yang telah disediakan dan diberikan dengan cara input apa saja perencanaan kinerjanya, lalu menginput pengukuran kinerja, kemudian melakukan pelaporan kinerja, selanjutnya evaluasi kinerja dan yang terakhir sistem akan bekerja untuk menilai keseluruhan data apakah suatu SKPD mampu melaksanakan kinerjanya dengan baik sehingga mampu dinilai prestasi kinerjanya dengan menghasilkan berupa ouput data informasi yang akan dilihat dan dinilai oleh masyarakat. Dan sistem E-SAKIP mampu menjamin sistem akuntabilitas kinerja instansi pemerintah mampu berjalan sesuai target yang dicapai sesuai dengan data yang ada dilapangan , karena sistem online data yang diinput kesistem tidak dapat di ubah. Sehingga kualitas kinerja dari suatu SKPD terukur dengan baik.

Berdasarkan hasil wawancara yang kami dapatkan dengan narasumber Bapak Ir. Made Budhi Setiawan, beliau mengatakan bahwa SKPD yang paling sering dalam mengalami kendala dalam pengaplikasian E-SAKIP adalah Dispenda Kab.Buleleng. Setelah itu, peneliti melakukan survei ke Dispenda Kab.Buleleng dan menemukan kendala dari pengaplikasian E-SAKIP di Dispenda Kab.Buleleng, yakni:

1. Dinas Pendapatan Kab.Buleleng mengalami beberapa kendala, diantaranya: sistem yang sangat rumit, sehingga menyebabkan pegawai bingung dalam menginput data, kesulitan dalam mengoperasikan E-SAKIP karena aplikasinya bersifat online, sehingga pada saat melakukan proses input data awal mengalami kekeliruan atau kesalahan data tidak dapat diubah . 
2. Dispenda Kab.Buleleng sering mengalami kesulitan karena peraturan sering berubah, sehingga perlu melakukan penyesuaian pada tahap teknis di Dispenda Kab.Buleleng, kesulitan dalam mengoperasikan E-SAKIP karena sering kali eror dan belum mahir dalam mengoprasikan aplikasi.

Saat kendala seperti diatas dialami oleh pihak pemerintahan desa, biasanya akan segera menghubungi secara langsung Bagian Organisasi Sekretariat Daerah Kabupaten Buleleng . Selain itu untuk memperlancar kinerja sistem E-SAKIP yang baru saja diterapkan ini, Bagian Organisasi Sekretariat Daerah melaksanakan peninjauan secara rutin ke setiap SKPD serta mengoptimalakan peninjauan dan pembimbingan terhadap SKPD yang masih sering mengalami kendala seperti Dinas Pendapatan Kab.Buleleng.

\subsection{Saran}

\subsubsection{Saran Bagi Penulis}

Dengan penulisan penelitian ini penulis tak lupa menyarankan bahwa isi dari pada penelitian ini sangat jauh dari penyempurnaan oleh karena itu penulis selalu menanti saran dari para saudara agar memperbaiki tulisan penelitian yang sempurna di masa yang akan datang.

\subsubsection{Saran Bagi Pembaca}

Mengingat masih terbatasnya kemampuan penulis dalam pembuatan penelitian ini, disarankan agar pembaca melakukan riset dan pembelajaran lebih lanjut mengenai pengelolaan kinerja instansi pemerintah dan penerapan E-SAKIP di SKPD masing-masing wilayah Pemkab/kota agar mengetahui dan mengawasi pengelolaan kinerja instansi di wilayah setempat.

4.2.3 Saran Bagi SKPD Dinas Pendapatan Kab. Buleleng

Diharapkan Dispenda Kab.Buleleng lebih baik lagi dalam menerapkan ESAKIP ini sehingga nantinnya SKPD lebih terbantu dalam hal menata kelola SAKIPnya agar lebih baik lagi sehingga transparansi dan akuntabilitasnya terjamin.

\section{Daftar Pustaka}

Abidin, Z. 2010. Evaluasi Terhadap Pelaporan Kinerja "Dinas Pendidikan" Kota Surabaya. Skirpsi. Sarjana Sekolah Tinggi Ilmu Ekonomi Indonesia, Surabaya.

Anthony, N. R. dan Govindarajan. 2005. Sistem Pengendalian Manajemen II. Jakarta : Salemba Empat.

Arja S. 2000. Jurnal Akuntansi \& Keuangan Vol.2,No.2 tentang akuntanbilitas dan pengukuran kinerja pemerintahan.

Bastian, I. 2006. Akuntansi Sektor Publik: Suatu Pengantar. Yogyakarta : Erlangga.

Djawa, I. 2013. Tinjauan terhadap LAKIP pada dinas pendapatan dan pengelolaan keuangan kota surabaya. Skripsi Sarjana Sekolah Tinggi Ilmu Ekonomi Indonesia, Surabaya.

Harun. 2009. Reformasi Akuntansi dan Manajemen Sektor Publik di Indonesia. Jakarta : Salemba Empat.

Mahsun, M. 2007. Akuntansi Sektor Publik Edisi Kedua. Yogyakarta : BPFEYOGYAKARTA.

Mahmudi. 2005. Manajemen kinerja Sektor Publik. Yogyakarta : UPP AMP YKPN.

Mardiasmo. 2002. Akuntansi Sektor Publik. Yogyakarta : ANDI OFFSET.

Nowardiawan, D. 2009. Akuntansi Sektor Publik. Jakarta : Salemba Empat.

Rasul, S, 2003. Pengintegrasian Sistem Akuntabilitas Kinerja dan Anggaran dalam Perspektif UU NO. 17/2003 Tentang Keuangan Negara. Jakarta : PNRI.

Republik Indonesia. 1999. Instruksi Presiden Republik Indonesia No. 7 tahun 1999 Tentang Akuntabilitas kinerja instansi pemerintah. Republik Indonesia. 2006. Peraturan Pemerintah

Republik Indonesia No. 8 Tahun 2006 Tentang Pelaporan Keuangan dan Kinerja Instansi Pemerintah. Republik Indonesia. 2010. 
Peraturan Menteri Negara Pendayagunaan Aparatur Negara No. 29 Tahun 2010 Tentang Pedoman Penyusunan Penetapan Kinerja dan Pelaporan Akuntabilitas Instansi Pemerintah. Republik indonesia. 2012.

Peraturan menteri pendayagunaan aparatur negara dan reformasi birokrasi republic Indonesia nomor 25 tahun 2012 tentang pelaksanaan evaluasi akuntanbilitas kinerja instansi pemerintah.

Ulum, I. 2004.Akuntansi Sektor Publik Sebuah Pengantar. Malang : Universitas Muhammadiyah Malang. 